\title{
Validity and Reliability Study for the Social and Emotional Competence Assessment Scale among 60-72 Months-old Children
}

\author{
Sevinç Ölçer \\ Correspondence: Sevinç Ölçer, Education Faculty, Department of Early Childhood Education, Mehmet Akif Ersoy \\ University, Burdur, Istiklal Campus, Turkey.
}

Received: December 26, 2016

Accepted: January 14, 2017 Online Published: January 16, 2017

doi:10.11114/jets.v5i3.2105

URL: http://dx.doi.org/10.11114/jets.v5i3.2105

\begin{abstract}
In the present study, the aim is to adapt the scale developed by Merrell, Felver-Gant and Tom (2011) to evaluate Social-Emotional Competence of Children and Young People among 60-72 months old children. Data have been obtained 200 preschool children attending preschool institutions. In testing validity of the scale, expert opinions are taken regarding scope and appearance validity. To test the construct validity of the scale, exploratory and confirmatory factor analysis techniques were used. As a result of exploratory factor analysis, it has been observed that variance of all items in the scale is loaded on three factors that explain $81.15 \%$ of the variance. As a result of the confirmatory factor analysis it has been noticed that all coefficients demonstrating the relationship between variables and factors observed in the model showing the factorial structure of this scale are sufficient. Internal consistency coefficients for each dimension and among total items of the scale have been calculated. T-test is conducted on independent sample and sub-, upper-groups and a meaningful difference at .001 level was found. Consequently, findings relating to validity and reliability of Social and Emotional Competence Assessment Scale for 60-72 Months Children have showed that the scale is a valid and reliable measurement tool.
\end{abstract}

Keywords: preschool, social and emotional competence, preschool teacher, assessment, scale development

\section{Introduction}

\subsection{Introduce the Problem}

Piaget suggests that there are four factors affecting the cognitive development. These factors are the maturation referring to development of central nervous system; physical experience referring to the interaction with objects; balancing process that child can change and regulate both his/her own structures and his environment in the face of environmental changes; and social experience. Within the scope of social experience, children's interaction with their peers and adult is referred (Oktay, 2004). In the social environment of developing child, other children are those mostly interacting with children after their family members. For the child in need of playing games and being included in a group, this social environment comprises of siblings, relatives and neighbors' children until the preschool period (Aydin, 1997).

In the preschool period, children must maintain a life in harmony with their inner worlds and the environment to achieve a healthy development socially and emotionally. Social development is a process of child's adaptation to the community she/he lives in. In this process, the child learns initial experiences of how to get in contact with people within their family as their first social surrounding. Interaction starting within the family continues with other adults and friend relations (Aral, Baran, Bulut and Cimen, 2000).

Social interactions result in changes primarily in an individual's thoughts and then his/her behaviors. In this respect, social interactions support not only cognitive but also social development (Salkind, 2004). Social and emotional learning emphasize the acquisition of important skills and qualifications related to individual's complete development from social, emotional and academic aspects all throughout life either in school life or outside school (Pasi, 2001).

According to Perry (1989), children develop five skills such as symbolization, indirect learning, self-regulation, self-efficacy and skill of foresight/foreseeing future results of current behaviors that are very important for social learning (cited, Elibol Gultekin, 2008). Social skills have an important place for social-emotional development of the child. Defined as the ability to behave accordingly in current social surrounding, social skills play an important role in terms of an individual's expressing positive or negative feelings properly, defending personal rights, demanding help 
from others if required, facilitating to reject inappropriate demands (Sorias, 1986). Social skills are those that allow to start and maintain positive social relations with others, such as communication, problem solving, decision making, self-management and peer relationships (www.behavioradvisor.com/socialskills. htm).

Skills required for children in communication and interaction process in their inner lives and the environment are discussed in the field literature with behaviors such as; accepting assistance, finishing an activity, talking, asking for help, joining a group, maintaining friendship, dealing with peer pressure, coping with open rejection, reacting to teasing, working in collaboration, leaving the group, working in a wide group, coping with shyness, working with small groups, working independently, entering a group in the classroom, joining the group discussions, joining an ongoing discussions, joining a group, coping with loneliness, coping with disappointment, coping with hidden rejection, making friends, playing with another person, avoiding conflict, playing within cooperation, accepting the new group member, playing in a wider group and working with another person.

Akfirat-Onalan (2006) defines social skills as individual's ability to behave in compliance with his/her own social environment. According to Westwood (1993), social skills are defined as important behaviors elements for individuals to start and maintain positive interactions with others. On the other hand, Cartledge and Milburn (1983) define social skills as "behaviors differing based on purposive social context, considered as socially appropriate, allowing positive reactions and preventing adverse reactions in interaction with others, also state-specific ones."

Sargent (1991) divides social skills into four groups including interpersonal start up behaviors such as commencing talks; interpersonal reactions such as responding to compliment; personal social behaviors such as coping with interpersonal disputes; and behaviors and skills revealed in certain environments (cited, Gulay and Akman, 2009). Calderalla and Merrell (1997) have found five dimensions in child and adolescent social skills including self-control skills, academic skills, adaptation skills and assertiveness skills (cited, Gulay and Akman, 2009; Avcioglu, 2005). According to Stephens (1978), social skills are discussed under four categories including behaviors regarding the self, behaviors regarding the duty, environmental behaviors and interpersonal behavior (cited, Bacanli, 2008).

In the field literature, social emotional skills also do not include a single field of skills but consist of higher level of skill fields covering a lot of skill, and they are considered with more than one dimension (Elias and Tobias, 1996; Elksnin and Elksnin, 2006; Gresham and Elliott, 1990; Marlow, Bloss and Bloss, 2000).

Social emotional learning skills are closely associated with emotional intelligence (Goleman, 2000), Gardner's multiple intelligences theory (Zins and Wagner, 1997), Greenberg's (2004) life skills approach, and social skills (McKenzie, 2004) and social learning (Frey, Nolen, Van Schoiack Edstrom and Hirschstein, 2005) approaches.

In studies where social and emotional learning skills are discussed together, these skills are classified in different formats such as problem solving skills (Cohen, 2001; Elias, 2001), skills increasing self-esteem (Cohen, 2001; Elias, 2006), skills of coping with stress (Kusché and Greenberg, 2001; Marlow, Bloss and Bloss, 2000), communication skills (Patti and Lantieri, 1999; Pasi, 2001). Although classifications are discussed under different category names, they resemble in many ways. On the other hand, social and emotional learning activities aiming at bringing in social and emotional skills may improve positive behaviors such as emotional understanding, cooperation, assertiveness, self-control, tolerating being blocked, using effective dispute solving strategies, and qualifications such as planning, mental flexibility, general health status, sexual development, school success (Joseph and Strain, 2003; Payton et al., 2000).

Learning, reinforcement and punishment, modelling and establishing identification with people around have significant contributions to children's social and emotional development and their socialization process. During the social development process, the child realizes that his/her behaviors are shaped by means of reinforcement and punishment. Children gain others' behavior patterns by observing others and doing what they do (Bandura, 1977, cited, Gander and Gardiner, 1998, p.276). Behaviors learned through modelling have a significant in the process of social development. Establishing relationship, conversations, asking questions, discussing, problem- solving styles are obtained through modelling (Ergene, 2011). Children's level of exhibiting dependent behavior, level of requiring discipline, type of discipline and their reaction to it are all closely related to the socialization process (Gander and Gardiner, 1998).

Considered as pioneer of an environmental approach, Bandura and Walters (1963) argue that there are different types of learning, and emphasized the role of learning through reinforcement focused observation, and that social behaviors such as aggression, resistance to provocation, postponing satisfaction and moral judgment are obtained in a wide range (Bandura, 1977, cited, Gruseck and Davidov, 2010). Bandura argues the importance of ideas about the fact that individual's self-organizing capacity refers to having the ability to control their own behaviors, self-judgment capacity refers to having the capacity to think about themselves, make judgments, reflect themselves, and their ideas about how much they are talented and sufficient in achieving any tasks. Bandura refers to this judgment relating to an individual's self as the self-efficacy (cited, Senemoglu, 2011). The more compatible an individual's efficacy perception is with 
his/her true self-efficacy, the more realistic an individual's effort towards activities, patience demonstrated when faced with difficulties, anxiety felt or the level of trust will be (Bandura, 1982, Senemoglu, 2011).

According to Vygotsky (1978), social experiences are of great importance in children's lives. Social experiences allow children to learn new behaviors and skills through imitation (cited, Fawcett and Garton, 2005). While children with social competence are more compatible with her friends and more successful academically, children without social competence are aggressive and incompatible in peer relationships.

In obtaining social-emotional features, child's interaction with environment is important as much as child's innate properties. Vygotsky emphasizes that all developmental skills initially begin at interpersonal levels or with interactions between children and more competent members of society (Fivush, Haden and Reese, 2006). Children shape their understanding about right and wrong behaviors by means of bidirectional interactions and conversations they perform with their parents, brothers and peers (Cassidy, Werner, Rourke and Zubernish, 2003).

Ability to conceptualize the mental states and, in this wise, explaining and predicting others' behaviors are considered as a key aspect of social cognition (Baron-Cohen, Leslie and Frith, 1985; Herold, Tényi, Lénárd and Trixler, 2002). Children begin to understand many mental states implicitly and manage their behaviors according to others' behaviors at the age of two (Figueras-Costa and Harris, 2001; Frith and Frith, 2003; Marschark, Green, Hinmarsch and Walker, 2000; Santrock, 2015).

Children around the age of three show tendency to establish basic causal relationships between requests, results, emotions and movements (Bartsch and Wellman, 1994; Flavell, 2000). According to Lillard and Flavell (1992), 3-year-old children understand some aspects of connections between people's ideaas or feelings and their behaviors. Children's emotional expressions are based on their ability to interpret emotional clues of others. At the age of four or five, children are able to evaluate reason for many basic emotional responses correctly (cited Berk, 2003). The information children have regarding emotions helps to a great extent in their efforts to get along with others. This sort of information is found associated with peer acceptance and enthusiasm to correct the situation when harming another child (Cassidy et al., 2003; Dun, Brown and Maguire, 1995, Garner and Jones and Miner, 1994, cited, Berk, 2003). Information about emotions such as understanding emotional symptoms is positively associated with social competence of 3-5 year old children; and negatively associated with internalization problems such as high level of anxiety and externalization such as high level of aggressive behavior (Trentacosta and Fine, 2009).

When children reach the age of six, they begin to learn how social relationships are established and how to live together with people and friends outside the family. During this period, harmony and cooperation improve. They begin to understand others better with empathy (Poole et al., 2003). According to Ironsmith and Poteat (1990), preschool children evaluated as more social by their teachers and those seeking more positive interaction with their classmates are more likely to be found popular by their peers. Child's being lovable is seen related with emotional signals sent around its environment in a way.

While children's emotional signals such as smiling, crying, careful attention affect others' behaviors, others' emotional reactions can also determine the social behavior of children (Berk, 2003; Bridgett et al., 2009). There is a strong correlation between social behaviors and emotional development, emotional reactions. Social relationships of impulsive children who can't control their emotions may be affected in a negative way. Emotions have a strong role in determining child's success in peer relationships (Howes, 2009).

Ramani et al. (2010), in their study of positive-negative peer interactions among 3-4 years-old children, observed that preschool children with better impulse control and who were more compatible and had less opposition to adults, tend to participate in games and game contents positively and in a more friendly and less negative way with their peers. Costin and Jones (1992), in their study, "Friendship as the Facilitator of Prosocial Measures and Emotional Sensitivity among Small Children", examined 4-6,5 year old preschool children's reactions to situations for which their friends and acquaintances might feel anger and fear. They found that children exhibited more emotional participation (empathy) and understanding the situation of their friends (sympathy) when compared with their acquaintances, and they often attempted to eliminate negative emotions. In addition, it was revealed that children show more empathy in situations involving anger and more sympathy in situations involving fear.

In connection with social skills, Mc Fall (1982) defines the term of social competence as the assessment based on result or judgment showing how an individual carries out his/her task/roles. These judgments are generally based on a comparison with ideas of others such as friend, family and teacher or with a norm group or another criteria (cited, Avcioglu, 2005).

Gresham and Reschly (1981) describe the social competence in two separate dimensions. These are adaptive behavior and social skills. Adaptive behavior includes children and young people's independent functional skills, physical 
development, academic proficiency and language development. Social skills, however, consist of three sub-dimensions. These dimensions are interpersonal behaviors, an individual's behaviors associated with himself/herself, and behaviors associated with his/her tasks. Interpersonal behaviors includes acceptance of authority, speaking skills, cooperation and game behaviors. An individual's behaviors associated with himself/herself; consist of behaviors such as expressing feelings, moral behavior, developing positive attitude towards himself/herself. An individual's behaviors associated with his/her tasks includes behaviors such as paying attention to warnings, fulfilling responsibilities, following directions and working independently (cited, Avcioglu, 2005). Gresham (1987) added a third sub-dimension to social competence as "peer acceptance". Peer acceptance is both a part of social competence and a result of adequate social behaviors (cited, Avcioglu, 2005).

According to McFall (1982), competence is a general assessment term which refers to the quality or suitability of an individual's general performance in a certain task. Based on this fact, social competence can be discussed as the result of an assessment according to a certain criterion or a group of criterion about whether an individual's performance in a social situation is suitable or not. According to Mc Fall, competence is not in performance but in assessment of the performance (cited, Bacanli, 2008).

Coleman (1992), on the other hand, indicates that social competence consists of three sub-dimensions including social skills, emotional factor and self-control. It is emphasized that the first sub-dimension of social competence, namely social skills, are used for effective communication with other people, such skills may include verbal skills such as starting conversation and non-verbal or cognitive skills such as working independently. Social skills may facilitate an individual's defending his/her personal rights, ability to reject unwanted requests, and requesting help from others when needed (cited, Sorias, 1986).

Emotional competence is the level of having ability to define emotions during social interactions, regulate and management emotions (Lindsey and Colwell, 2003). In emotional competence, emotional cognition referred to as an individual's ability to recognize and interpret his/her own and others' emotions, emotional regulation that could be summarized as adaptation of feelings to external environment, and social competence are important factors. Emotionally decent children tend to be more successful in social interactions.

As can be seen in the field literature, social-emotional skills and competencies are described as similar, and they are provided in different approaches and categories by different experts. In identifications and classifications, individual and social aspects of social emotional skills are emphasized. Considering from an individual perspective, while an individual's ability to control emotions and behaviors, self-esteem, self-confidence and self-value perceptions are important; considering from a social perspective, starting and maintaining communication, adapting to group, fulfilling the responsibilities, expressing opposition adhering to politeness criteria in situations where he/she does not agree with others, overcoming social problems come into prominence. The remarkable point in classifications is that not only social development but also cognitive and emotional development are effective on social skills. In parallel with child's cognitive development and as a result of experiences, types of emotions he/she feels increase, he/she learns different way of expressing emotions, at the same time, behaviors in social interactions are shaped after he/she learns a separate individual in the family about three old year and after entering into interaction-communication with the environment outside family.

\subsection{Explore Importance of the Problem}

In the present study, the aim is to adapt the scale developed by Merrell, Felver-Gant and Tom (2011) to evaluate Social-Emotional Competence of Children and Young People among 60-72 months old children. In children's acquisition of social and emotional skills, preschool education and teachers play a significant role. In this context, appropriate training programs can be developed to support these skills by evaluating both children's social and emotional skills through a single scale.

In Turkey, there are preschool social skills assessment scales available including Social Skills Rating System Scale (SSRS) adopted by Elibol Gultekin (2008) from Gresham and Elliot (1990) consisting of "cooperation," "self-expression/assertiveness" and "self-control" sub-dimensions; 4-5 Year Old Children's Behavior Rating Scale developed by Cagdas (1997) consisting of "cooperation," "social relationship" sub-dimensions; and preschool social skills assessment consisting of 49 items and four sub-dimensions developed by Omeroglu at al. (2014). It is observed that studies in our country generally focus on social skills and the only scale assessing social and emotional competencies in an integrated way is the Infant Toddler Social and Emotional Assessment (ITSEA) Tool adopted by Kandir and Alpan (2008) from Carter and Briggs-Gowan (1988) with the aim of evaluate 12-36 month old children's social and emotional skills. For this reason, in this study, the aim is adaption of the scale developed by Merrell, Felver-Gant and Tom (2011) with a view to assess 60-70 month old children's social and emotional competencies. 


\section{Method}

\subsection{Identify Subsections}

The method section includes (a) firstly, the study of linguistic equivalence of the scale; (b) characteristics of participants and (c) the psychometric properties of the data collection instrument.

\subsection{Sampling Procedures}

\subsubsection{Linguistic Equivalence}

In English-Turkish translation of the scale developed by Merrell, Felver-Gant and Tom (2011) with the aim of assess Social and Emotional Competences of Children and Youth (around 6 and 9-12), the five-stage model suggested by Brislin, Lonner and Thorndike (1973) is used. According to the model, the first translation from source language consists of stages of assessment of first translation, re-translation to source language, evaluation of equality of translation to source language and original scale, and final evaluation by experts (Hambleton, 2005). In the first stage, translation of the scale from source language to target language has been conducted by two assistant professor whose native language is Turkish and who have full command in English language. The scale has been translated into source language by two foreign language lecturer who are in command of both the subject and language at the same level. Item expressions of the original and translated scale is compared and their equivalence has been determined. After this process, scale items and each word has been reviewed by lecturer conducting the translation and an assistant professor of Turkish Language and Literature according to used current language, explicitness and clarity of expressions, and consistency with the original scale has been ensured.

\subsubsection{Participants}

The study universe consists of official kindergarten and preschool classrooms bound to the Ministry of Education in the city center of Burdur. To the study, a total of randomly determined 60-72 month old 200 children including 105 girls and 95 boys and 20 preschool teachers have participated. 52.5\% of participant children are female, and $47.5 \%$ of them are male.

\subsubsection{Data Collection Instruments}

In the study, as the data collection tool, 5-item Likert-type form developed to assess Children and Young People's Social-Emotional Competencies and consisting of 39 items by Merrell, Felver-Gant and Tom (2011) adopted to Turkish children was used. The scale consisted of "Self-regulation/Responsibility," "Social Competence" and "Empathy" sub-dimensions. In self-regulation/responsibility sub-dimension, there were 22 items and they met $39.00 \%$ of the variance. Cronbach's Alpha Reliability Coefficient was found as .95. Social competence sub-dimension consisted of 10 items, and while it met $5.86 \%$ of the variance, Cronbach's alpha reliability coefficient was .89 . Empathy, as the third sub-dimension, consisted of 7 items and it met $3.56 \%$ of the variance. Cronbach's Alpha reliability coefficient was found as .87 . It has been concluded that the scale explains $48.42 \%$ of the total variance. The scale total Cronbach's Alpha reliability coefficient was found as .96 . Factor loads of items varied between $.067-.071$. It has been found that three-factor model has good level acceptable fit index ( $22=4027.53, \mathrm{df}=692, \mathrm{v} 2 / \mathrm{df}=5.82)$ : CFI $=.85, \mathrm{TLI}=.84$, RMSEA $=.069$, SRMR $=.063)$, it demonstrates better compatibility than two-level hierarchical structure $(\mathrm{v} 2=6350.31$, $\mathrm{df}=695, \mathrm{v} 2 / \mathrm{df}=9.137): \mathrm{CFI}=.74, \mathrm{TLI}=.73, \mathrm{RMSEA}=.088, \mathrm{SRMR}=.079)$, all chi-square values were found significant at 0.05 level statistically. Based on the criteria, while a meaningful relationship at .01 level was found statistically between Social Skills Rating Scale [SSRS] (Gresham and Elliott, 1990) consisting of 55 items in four sub-dimensions such as "Cooperation," "Aggression," "Responsibility" and "Self-possession/self-regulation", meaningful relationship at .001 level was found between The Social Competence Scale of the Home and Community Social Behavior Scales [HCSBS] (Merrell and Caldarella, 2002) containing a total of 32 items and consisting of two sub-dimensions such as "Peer relationships" and "Self-regulation".

In the first stage of adaptation study, linguistic equivalence of the scale was ensured. After this process, the scale was submitted to opinions of six instructor who are expert in child development and preschool education, guidance and psychological counseling and program development fields from the point of scope, appearance, Turkish culture and suitability for children with its 39 items as in the original. Based on feedbacks from experts, necessary arrangements were made on the scale and the scale specified with a total of 31 items was presented to 20 teachers with a view to assess social and emotional competence of 60-72 month old children including 105 girls and 95 boys attending preschool education institutions in Burdur. The data was obtained through assessment by 20 teachers towards their students. 


\section{Results}

\subsection{Validity Study of the Scale}

Containing 39 items in the original, the scale was submitted for reviews of field experts in child development and preschool education, guidance and psychological counseling, program development areas in terms of compliance with the Turkish culture, scope and appearance validity. Following the expert opinion, items disagreed upon were removed from the scale, some items were applied with arrangements. In addition, on the grounds that it will take time for teachers to fill out the scale separately for each child, they will be distracted and this will affect objective assessment, the scale has taken its final form in a way to include 31 items as required. Exploratory and confirmatory factor analysis for construct validity of the scale were applied.

\subsubsection{Construct validity}

Explanatory and confirmatory factor analyzes were performed to determine the validity of the construct of the scale.

\subsubsection{Explanatory Factor Analysis}

Using the Principal Component Factor Analysis that is an element of exploratory factor analysis, it has been analyzed how many factors there are in structure of the scale. Factor load value-eigen- is the coefficient explaining relationship of items with factors. When this value is 0.45 and higher, it is considered to be a criterion for a good selection. In factor analysis, the aim is to maximize common variance or common factor variance caused by factors on each variable (item). In multifactorial scales, common factor variances of items must be close to 1 (over 0.66) (DeVellis, 2003; Tezbasaran, 1997). In internal analyses, Kaiser's Rule (for instance, an eigen value equals to 1, Kaiser, 1960. Cited, Merrell, Felver-Gant ve Tom, 2011) was applied to reveal factors.

In Table 1, factor loads, item total correlations and Cronbach's Alpha values relating to Social and Emotional Competence Assessment Scale for 60-72 Month Old Children are presented.

Table 1. Factor Loads, Item Total Correlations and Cronbach's Alpha Values relating to Social and Emotional Competence Assessment Scale for 60-72 Month Old Children

\begin{tabular}{|c|c|c|c|c|c|c|}
\hline Items & Items Descriptions & $\begin{array}{l}\text { FL } \\
\text { 1. Factor } \\
\text { Social-Emotional } \\
\text { Competence }\end{array}$ & $\begin{array}{l}\text { FL } \\
\text { 2. Factor } \\
\text { Self-regulation/Re } \\
\text { sponsibility }\end{array}$ & $\begin{array}{l}\text { FL } \\
\text { 3. Factor } \\
\text { Self-control }\end{array}$ & ITC & CA \\
\hline 1 & Actions in advance.... & .81 & .24 & .14 & .76 & .98 \\
\hline 2 & Friendship with others.... & .80 & .40 & .24 & .83 & .97 \\
\hline 3 & Friends in difficult situation... & .71 & .40 & .24 & .82 & .98 \\
\hline 4 & Friends with him/her...... & .77 & .33 & .33 & .86 & .97 \\
\hline 8 & Friends think of him/her..... & .78 & .41 & .29 & .90 & .97 \\
\hline 10 & Problems....... & .70 & .31 & .50 & .89 & .97 \\
\hline 11 & For others......... & .65 & .33 & .46 & .85 & .98 \\
\hline 12 & Time with friends......... & .77 & .39 & .30 & .85 & .97 \\
\hline 13 & Others' perspective ...... & .68 & .47 & .35 & .91 & .97 \\
\hline 14 & Good with friends ........ & .70 & .52 & .32 & .89 & .97 \\
\hline 16 & $\begin{array}{l}\text { Suitable to the leve of } \\
\text { development faced......... }\end{array}$ & .64 & .55 & .38 & .85 & .97 \\
\hline 20 & Among his friends ........ & .73 & .49 & .21 & .91 & .98 \\
\hline 27 & When people are sad ...... & .63 & .41 & .48 & .85 & .97 \\
\hline 29 & His/her friends............. & .69 & .45 & .33 & .88 & .97 \\
\hline 17 & $\begin{array}{l}\text { The problems faced in } \\
\text { activities........ }\end{array}$ & .51 & .61 & .43 & .82 & .95 \\
\hline 18 & When appropriate....... & .14 & .83 & .41 & .82 & .96 \\
\hline 19 & Responsibility in activities..... & .43 & .71 & .36 & .86 & .95 \\
\hline 22 & While talking with others..... & .51 & .71 & .16 & .87 & .96 \\
\hline 23 & Negative feelings....... & .58 & .67 & .28 & .65 & .95 \\
\hline 24 & Other people ......... & .51 & .60 & .40 & .62 & .96 \\
\hline 30 & Self............... & .51 & .72 & .11 & .82 & .96 \\
\hline 31 & In projects, independent... .... . & .48 & .74 & .22 & .85 & .95 \\
\hline 5 & When got angry............... & .16 & .20 & .78 & .60 & .88 \\
\hline 6 & Reviews....... & .28 & .13 & .81 & .65 & .87 \\
\hline 9 & Regarding others........... & .56 & .31 & .61 & .85 & .87 \\
\hline \multirow[t]{2}{*}{15} & Intemperate behaviors & & & & & \\
\hline & by peers........ & .19 & .23 & .79 & .62 & .88 \\
\hline 21 & In the face of problems...... & .39 & .34 & .67 & .89 & .87 \\
\hline
\end{tabular}


As can be seen in Table 1, factor loads of items in social emotional competence sub-dimensions vary between $0.63-0.81$, factors loads of items in self-regulation/responsibility dimension vary between $0.60-0.83$, and factor loads in self-control sub-dimension vary between 0.61-0.81.

Mean, standard deviation and correlation values are presented in Table 2. for social competence sub-dimension of Social and Emotional Competence for 60-72 Month Old Children scale, in Table 3. for self-regulation/responsibility sub-dimension of Social and Emotional Competence for 60-72 Month Old Children scale, and in Table 4. for self-control sub-dimension of Social and Emotional Competence for 60-72 Month Old Children scale.

Table 2. Mean, standard deviation and correlation values for First Factor Social Emotional Competence sub-dimension items

\begin{tabular}{|c|c|c|c|c|c|c|c|c|c|c|c|c|c|c|}
\hline Items & 1 & 2 & 3 & 4 & 8 & 10 & 11 & 12 & 13 & 14 & 16 & 20 & 27 & 29 \\
\hline 1 & 1,000 & & & & & & & & & & & & & \\
\hline 2 & 811 & 1,000 & & & & & & & & & & & & \\
\hline 3 & 669 &, 778 & 1,000 & & & & & & & & & & & \\
\hline 4 &, 762 & 845 &, 743 & 1,000 & & & & & & & & & & \\
\hline 8 &, 747 & 846 &, 742 &, 863 & 1,000 & & & & & & & & & \\
\hline 10 &, 708 & 800 &, 781 & ,778 &, 821 & 1,000 & & & & & & & & \\
\hline 11 & 670 & ,754 & ,778 & ,724 & ,785 & ,787 & 1,000 & & & & & & & \\
\hline 12 &, 715 & 814 &, 710 & 821 & 879 & 832 &, 780 & 1,000 & & & & & & \\
\hline 13 & 671 & 807 & ,780 & ,729 & ,832 & 825 & ,786 &, 864 & 1,000 & & & & & \\
\hline 14 &, 718 & 872 &, 762 & 834 & 865 & 832 & ,744 & 858 &, 859 & 1,000 & & & & \\
\hline 16 &, 731 & 840 &, 748 & 818 &, 845 & 791 & 762 & 807 & 830 & 840 & 1,000 & & & \\
\hline 20 & 671 & 815 &, 735 & 822 & ,884 & ,769 & ,704 & 810 & 818 & 834 &, 800 & 1,000 & & \\
\hline 27 & 672 & ,776 & ,760 & 741 & 815 & 846 & ,798 & ,781 & ,786 & 818 & 824 & 728 & 1,000 & \\
\hline 29 &, 727 & ,820 & ,708 & ,853 & 815 & ,758 & ,719 & 819 & ,774 & ,859 & ,818 & ,795 & 804 & 1,000 \\
\hline Mean & 3,49 & 3,91 & 4,00 & 3,75 & 3,55 & 3,81 & 3,79 & 3,68 & 3,56 & 3,71 & 3,65 & 3,57 & 3,82 & 3,79 \\
\hline $\mathrm{Sd}$ & 1,12 & 1,05 &, 92 & 1,03 & 1,12 & 1,12 & 1,03 & 1,06 & 1,18 & 1,15 & 1,11 & 1,24 & 1,10 & 1,00 \\
\hline
\end{tabular}

Table 3. Mean, standard deviation and correlation values for second factor Self-Regulation/Responsibility sub-dimension items

\begin{tabular}{|c|c|c|c|c|c|c|c|c|}
\hline & 17 & 18 & 19 & 22 & 23 & 24 & 30 & 31 \\
\hline 17 & 1,000 & & & & & & & \\
\hline 18 & ,728 & 1,000 & & & & & & \\
\hline 19 &, 850 & ,774 & 1,000 & & & & & \\
\hline 22 & ,746 & ,724 &, 733 & 1,000 & & & & \\
\hline 23 & ,827 & ,753 & ,820 & ,784 & 1,000 & & & \\
\hline 24 & ,826 & ,729 & ,753 & 678 & ,860 & 1,000 & & \\
\hline 30 & 697 & ,725 & ,762 & ,859 & ,790 & ,641 & 1,000 & \\
\hline 31 & ,821 & ,745 & ,860 & ,754 & ,862 & ,821 & ,784 & 1,000 \\
\hline Mean. & 3,71 & 3,71 & 4,05 & 3,66 & 3,70 & 3,85 & 3,72 & 3,88 \\
\hline $\mathrm{Sd}$ & 1,13 & 1,13 & 1,06 & 1,15 & 1,17 & ,98 & 1,13 & 1,08 \\
\hline
\end{tabular}

Table 4. Mean, standard deviation and correlation values for third factor Self-Control sub-dimension items

\begin{tabular}{|c|c|c|c|c|c|}
\hline Items & 5 & 6 & 9 & 15 & 21 \\
\hline 5 & 1,000 & & & & \\
\hline 6 & ,643 & 1,000 & & & \\
\hline 9 & 633 &, 674 & 1,000 & & \\
\hline 15 & ,584 & 641 & ,620 & 1,000 & \\
\hline 21 &, 595 &, 701 & 682 &, 682 & 1,000 \\
\hline Mean & 3,90 & 3,72 & 3,88 & 3,69 & 3,54 \\
\hline $\mathrm{Sd}$ &, 88 & ,98 & 1,02 & 1,00 & 1,05 \\
\hline
\end{tabular}

As a result of the first analysis, it has been observed that the first three items meet .79 .7 of the variance. As a result of basic component analysis, three components (factors) have been determined. Considering factor loads of items, 7th-25th-28th items observed as giving high level of loads in both factors were removed from the scale, as a result of 
the second (varimax rotation) analysis, the 25th item was removed from the scale and a third analysis was performed. In this final analysis, according to Bartlett test results $\left(\mathrm{x}^{2}=8043,416 \mathrm{Sd}=378, \mathrm{p}<.000\right)$, it has been observed that Kaiser-Meyer-Olkin sample adequacy measurement (.93) is significant. As a result of related factor analysis, it is observed that variance of all items in the scale is loaded on three factors that explain $81.15 \%$ of the variance. Factor loads of all items of the scale range from .60 and .83 (see Table 1).

\subsubsection{Confirmatory Factor Analysis}

The first and second level of confirmatory factor analysis (CFA) were used to analyze whether the factor structure of the scale was verified. Confirmatory factor analysis (CFA) aims at assessing how much a factorial model comprised of factors with many observable variables (latent variables) complies with real data. The model to be analyzed may define a structure that has been determined using data from an empirical study or fictionalized based on a certain theory (Sumer, 2000). To assess the validity of model in CFA, a large number of fit indices were used. The most frequently used fit indices among these are (Cole, 1987; Sumer, 2000); Chi-Square Fit Indice Test (Chi-Square Goodness, $\chi^{2}$ ), Root Mean Square Error of Approximation (RMSEA), Comparative Fit Index (CFI), Non-Normed Fit Index (NNFI), Normed Fit Index (NFI) and Goodness of Fit Index (GFI). The fact that values observed in scale model are in the range of $\mathrm{X} 2 / \mathrm{d}<3 ; 0<\mathrm{RMSEA}<0.05 ; 0.97 \leq \mathrm{NNFI} \leq 1 ; 0.97 \leq \mathrm{CFI} \leq 1 ; 0.95 \leq \mathrm{GFI} \leq 1$ and $0.95 \leq \mathrm{NFI} \leq 1$ show the perfect fit; the range of $4<\mathrm{X} 2 / \mathrm{d}<5 ; \quad 0,05<\mathrm{RMSEA}<0.08 ; \quad 0.95 \leq \mathrm{NNFI} \leq 0.97 ; \quad 0.95 \leq \mathrm{CFI} \leq 0.97 ; \quad 0.90 \leq \mathrm{GFI} \leq 0.95$ and $0.90 \leq \mathrm{NFI} \leq 0.95$ shows acceptable fit (Kline, 2005; Sumer, 2000).

CFA was applied with a view to assess whether 27-item structure of three dimensions of the scale was verified. In the first applied CFA, items with a statistically non-significant $t$ value were examined. According to examination, it was determined that there were no items with non-significant $t$ value. All items maintained their positions in scale. Path diagram is given in Figure 1.

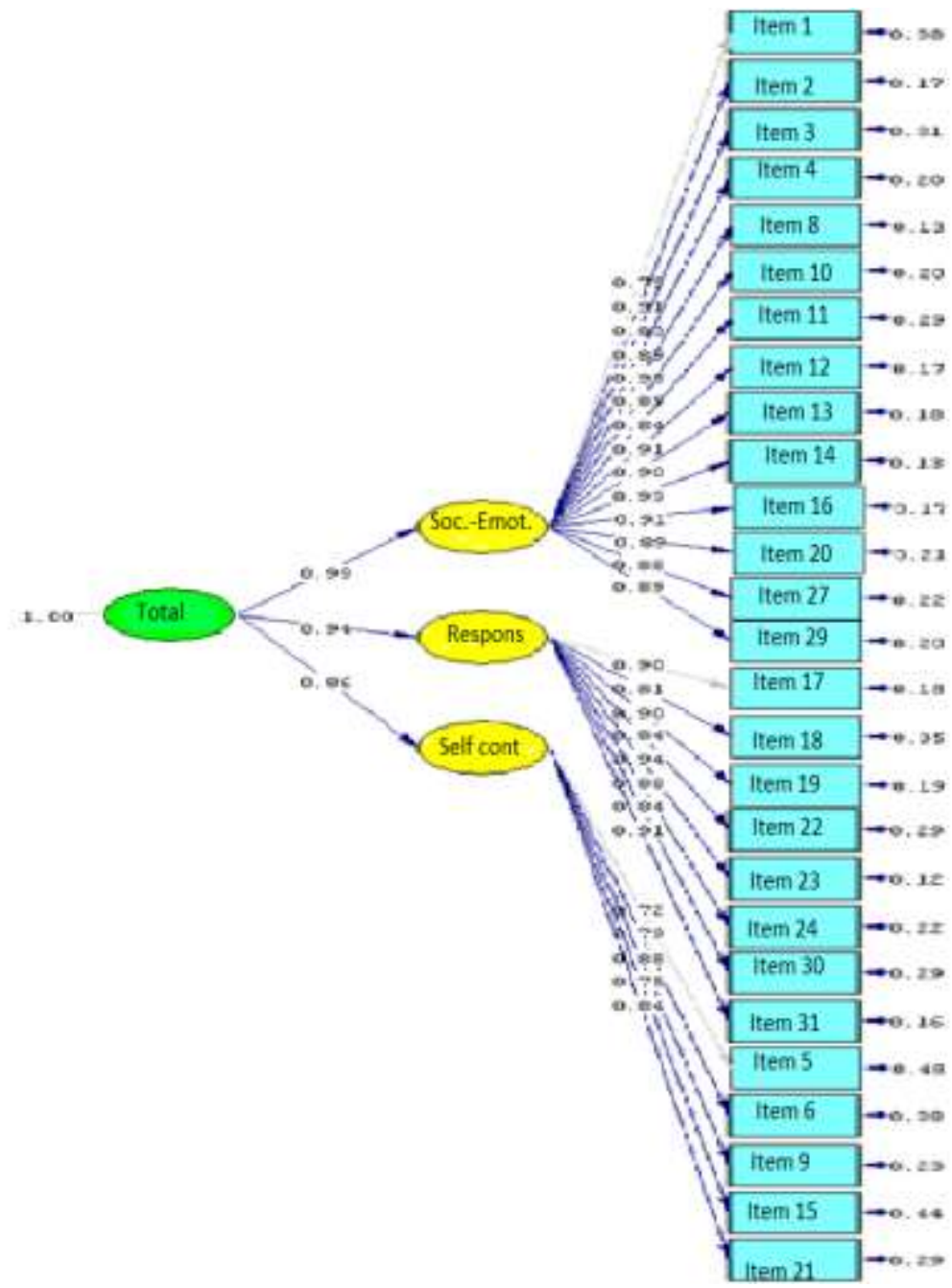

Figure1. Path Diagram relating to the Scale 
Fit indices were found as $\chi^{2}=149.71, \mathrm{X}^{2} / \mathrm{sd}=4.65, \mathrm{CFI}=0.95$, IFI=0.95, NNFI=0.95 and NFI=0.94. Analyzing coefficients that show the relationship between factors and observed variables of the model giving the factorial structure of this scale, it has been concluded that all coefficients are at a sufficient level. Considering fit statistics calculated harmony with CFA, it has been concluded that previously determined structure of the scale generally complies with collected data.

Regression values and $\mathrm{t}$ values relating to Social and Emotional Competence Assessment for 60-72 Month Old Children Scale items are presented in Table 5.

Table 5. Regression and t values relating to the Social and Emotional Competence Assessment for 60-72 Month Old Children Scale items

\begin{tabular}{llcccc}
\hline Items & Regression values & t values & Items & Regression values & t values \\
\hline 1 & 0.96 & 15.52 & 17 & 0.75 & 8.76 \\
2 & 0.77 & 13.58 & 18 & 0.97 & 16.02 \\
3 & 0.92 & 15.07 & 19 & 0.98 & 20.40 \\
4 & 0.63 & 10.82 & 20 & 0.92 & 14.98 \\
5 & 0.78 & 16.07 & 21 & 0.95 & 11.50 \\
6 & 0.97 & - & 22 & 0.98 & 17.54 \\
7 & - & 14.72 & 23 & 0.89 & 23.17 \\
8 & 0.91 & 11.99 & 24 & 0.97 & - \\
9 & 0.96 & 15.11 & 25 & - & -53 \\
10 & 0.88 & 13.88 & 26 & 0.98 & - \\
11 & 0.97 & 15.58 & 27 & - & 14.83 \\
12 & 0.98 & 15.33 & 28 & 0.97 & -15.09 \\
13 & 0.97 & 16.14 & 29 & 0.90 & 17.37 \\
14 & 0.98 & 10.26 & 30 & 0.95 & 21.43
\end{tabular}

Analyzing the Table 5, it has been determined that regression coefficients and $\mathrm{t}$ values are significant ( $\mathrm{t}>1,92)$ and three-factor model is verified.

\subsection{The Scale Reliability}

The 7th, 25th and 28th items were removed from the scale as a result of the first varimax rotation during exploratory factor analysis conducted for the scale structure validity, and the 26th item was removed from the scale as a result of the second varimax rotation since they gave the same load rate on both dimensions. Cronbach's Alpha coefficient relating to internal consistency of a total 27-item scale was taken into consideration, Cronbach's Alpha value for the whole scale was found as .98. As a result of analyses, it has been observed that the scale items are gathered under three sub-dimensions as in the original scale, however, it has been determined that some items were assigned to different dimensions compared to the original form. In this case, sub-dimension items were re-analyzed by field experts and sub-dimensions were renamed.

Considering Cronbach's Alpha values calculated for each factor in itself, Cronbach's Alpha value of the first factor, "Social Emotional Competence," was found as .98; Cronbach's Alpha value of the second factor, "Self-Regulation/Responsibility," was found as .96, and the Cronbach's Alpha value of the third factor, "Self-Control Skills," was found as .90 .

Tezbasaran (1997) expresses that a reliability coefficient that can be considered sufficient in a Likert-type scale should be close to 1 as much as possible. According to these results, it is possible to say that reliability of the measurement instrument used for the research is high.

For the purposes of testing item discrimination, independent sample sub-upper group t test was conducted. Mean, standard deviation, $\mathrm{F}$ and $\mathrm{t}$ values and significance level of items are presented in Table 6).

When Table 6 is examined it can be seen that there is a significant difference between the sub and upper group scores in terms of items discrimination of the scale at .001 level. 
Table 6. Sub-Upper Groups t Test Results

\begin{tabular}{|c|c|c|c|c|c|c|c|}
\hline Items & group & $\mathrm{n}$ & $x^{2}$ & $\mathrm{Sd}$ & $\mathrm{F}$ & $\mathrm{t}$ & $\mathrm{p}$ \\
\hline \multirow[t]{2}{*}{1} & upper & 54 & 4,4444 &, 66351 & 2,088 & 14,943 &, 000 \\
\hline & sub & 54 & 2,2778 & ,83365 & & & \\
\hline \multirow[t]{2}{*}{2} & upper & 54 & 4,8889 & ,31722 & 54,585 & 20,262 & ,000 \\
\hline & sub & 54 & 2,6111 & ,76273 & & & \\
\hline \multirow[t]{2}{*}{3} & upper & 54 & 4,8519 & ,35858 & 16,953 & 17,537 & ,000 \\
\hline & sub & 54 & 2,9259 & ,72299 & & & \\
\hline \multirow[t]{2}{*}{4} & upper & 54 & 4,7222 & ,49208 & 18,018 & 17,393 & ,000 \\
\hline & sub & 54 & 2,6296 & ,73449 & & & \\
\hline \multirow[t]{2}{*}{5} & upper & 54 & 4,5185 & ,60628 & 1,300 & 9,564 & ,000 \\
\hline & sub & 54 & 3,1852 & ,82586 & & & \\
\hline \multirow[t]{2}{*}{6} & upper & 54 & 4,5741 & 63251 & 21,282 & 10,997 & ,000 \\
\hline & sub & 54 & 2,9074 & ,91669 & & & \\
\hline \multirow[t]{2}{*}{8} & upper & 54 & 4,6667 & ,51396 & 5,403 & 19,737 & ,000 \\
\hline & sub & 54 & 2,3333 & ,70040 & & & \\
\hline \multirow[t]{2}{*}{9} & upper & 54 & 4,8704 & ,33905 & 52,033 & 18,867 & ,000 \\
\hline & sub & 54 & 2,7407 & ,75698 & & & \\
\hline \multirow[t]{2}{*}{10} & upper & 54 & 4,9444 & ,23121 & 100,447 & 25,484 & ,000 \\
\hline & sub & 54 & 2,5000 & 66588 & & & \\
\hline \multirow[t]{2}{*}{11} & upper & 54 & 4,8519 & ,35858 & 34,626 & 24,864 & ,000 \\
\hline & sub & 54 & 2,5741 & ,56974 & & & \\
\hline \multirow[t]{2}{*}{12} & upper & 54 & 4,7593 & ,47325 & 16,497 & 19,938 & ,000 \\
\hline & sub & 54 & 2,4815 & 69338 & & & \\
\hline \multirow[t]{2}{*}{13} & upper & 54 & 4,7778 & ,46242 & 1,332 & 25,446 & ,000 \\
\hline & sub & 54 & 2,0926 & 62249 & & & \\
\hline \multirow[t]{2}{*}{14} & upper & 54 & 4,9074 &, 35120 & 63,072 & 22,899 & ,000 \\
\hline & sub & 54 & 2,3704 & ,73449 & & & \\
\hline \multirow[t]{2}{*}{15} & upper & 54 & 4,5000 & 63691 & 3,587 & 11,623 & ,000 \\
\hline & sub & 54 & 2,7778 & ,88310 & & & \\
\hline \multirow[t]{2}{*}{16} & upper & 54 & 4,7037 & ,50017 & 5,938 & 21,631 & , 000 \\
\hline & sub & 54 & 2,3148 & 63911 & & & \\
\hline \multirow[t]{2}{*}{17} & upper & 54 & 4,7593 & ,43155 & 4,535 & 25,516 & ,000 \\
\hline & sub & 54 & 2,3333 & ,54944 & & & \\
\hline \multirow[t]{2}{*}{18} & upper & 54 & 4,7407 & ,48312 & 44,674 & 14,224 & ,000 \\
\hline & sub & 54 & 2,5185 & 1,04142 & & & \\
\hline \multirow[t]{2}{*}{19} & upper & 54 & 5,0000 &, 00000 & 140,332 & 19,512 & ,000 \\
\hline & sub & 54 & 2,8704 & ,80203 & & & \\
\hline 20 & upper & 54 & 4,7222 & ,49208 & 5,991 & 21,681 & ,000 \\
\hline & sub & 54 & 2,1296 & ,72804 & & & \\
\hline 21 & upper & 54 & 4,5556 & 63444 & 1,095 & 15,881 &, 000 \\
\hline & sub & 54 & 2,4815 & ,72008 & & & \\
\hline 22 & upper & 54 & 4,7963 & ,56233 & 30,265 & 15,614 & ,000 \\
\hline & sub & 54 & 2,4259 & ,96352 & & & \\
\hline 23 & upper & 54 & 4,9259 & ,32805 & 62,620 & 24,503 &, 000 \\
\hline & sub & 54 & 2,2963 & ,71717 & & & \\
\hline 24 & upper & 54 & 4,8148 & ,43758 & 14,856 & 21,661 & , 000 \\
\hline & sub & 54 & 2,6667 & ,58277 & & & \\
\hline 27 & upper & 54 & 4,9815 & ,13608 & 255,184 & 30,326 & ,000 \\
\hline & sub & 54 & 2,5556 & ,57188 & & & \\
\hline 29 & upper & 54 & 4,9074 & 35120 & 40,302 & 22,361 &, 000 \\
\hline & sub & 54 & 2,7037 & 63334 & & & \\
\hline 30 & upper & 54 & 4,9074 &, 35120 & 65,735 & 16,030 & ,000 \\
\hline & sub & 54 & 2,6481 & ,97434 & & & \\
\hline 31 & upper & 54 & 4,9259 & ,26435 & 42,593 & 19,263 &, 000 \\
\hline & sub & 54 & 2,6481 & ,82776 & & & \\
\hline
\end{tabular}

$\mathrm{p}<.001$

\section{Discussion}

In the present study, the objective is to adapt the Social-Emotional Competence Assessment of 60-72 Month Old Children scale developed by Merrell, Felver-Gant and Tom (2011) into Turkish children. After completion of Turkish translation by means of the method developed by Brislin et al. (1973), the scale was submitted for reviews of field experts in child development and preschool education, guidance and psychological counseling, program development areas in terms of scope and appearance validity of the scale; some items were arranged following these expert opinions, and the scale with its final format was presented to teachers for assessing 105 girls and 95 boys in the range of 60-72 
month old. Exploratory and confirmatory factor analysis for construct validity of the scale were applied. The structure consisting of three factors as in the original scale was verified, however, it has determined that some items give loads to different dimensions compared to the original scale. By taking opinions of field experts again, items relating to sub-dimensions were arranged in accordance with expert opinions, "Self-regulation/Responsibility," "Social Competence" and "Empathy" sub-dimensions found in the original scale were renamed as "Social-emotional competence," "Self-regulation/responsibility" and "Self-control". The first and second level of confirmatory factor analysis (CFA) have been used to analyze whether the factor structure of the scale is verified. Fit indices are found as $x^{2}$ $=149.71, \mathrm{X}^{2} / \mathrm{sd}=4.65, \mathrm{CFI}=0.95, \mathrm{IFI}=0.95, \mathrm{NNFI}=0.95$ and $\mathrm{NFI}=0.94$. It has been noticed that all coefficients demonstrating the relationship between variables and factors observed in the model showing the factorial structure of this scale is sufficient.

In findings relating to reliability of the scale, it has been observed that internal consistency coefficient for all factors is at sufficient level. It is considered significant from the point of item validity that factor loads of all items in the scale vary between .60 and .83 . In the literature, while it is considered as a good indicator that item factor loads are $0.40-0.45$ and higher, it is expected that Cronbach's Alpha value is 0.70 and higher (DeVellis, 2003; Tezbasaran, 1997). In this study, this value was determined as .98 for social emotional sub-dimension, .96 for self-regulation/responsibility sub-dimension and .90 for self-control sub-dimension. Considering the item discrimination to distinguish the difference between sub and upper groups of items, a meaningful at level of .001 was found statistically.

Kara and Cam (2007), in their validity and reliability study carried out with pre-service teachers for the social skill assessment scale that consisted of sub-dimensions such as "Skills of group conducting and executing", "skills of starting and resuming relationship" and "self-control skills", determined that scores by the experiment group in development learning course, which was taught via drama method, were higher than those by the control group in all sub-dimensions of the scale.

Omeroglu et al. (2014), in their validity-reliability study, determined that scores by 5-year-old group children were higher than those by 3 and 4-years-old group in sub-dimensions of "Starting Skills", "Academic Skills", "Friendship Skills" and "Emotions Managing Skills" in "The Preschool Social Skills Assessment Scale". Cronbach'n Alpha reliability coefficients of the scale were found as .89 for "Starting skills", .88 for "Academic Skills", .92 for "Friendship Skills" and .92 for "Emotional Managing Skills". Similarly, in the sub-dimension, "Emotion Managing Skills" of the scale, Cronbach'n Alpha reliability coefficient for "Social Emotional Competence" sub-dimension was found as .98 in the present study.

In line with the findings obtained in the study, we can say that the scale adapted towards assessment of social and emotional competence of 60-72 month old children is a valid and reliable measurement tool.

Exploratory and confirmatory factor analyses required to test availability of the scale in another culture, and validity and reliability status determined by means of Cronbach's Alpha internal consistency coefficient are limited to data obtained from participants determined randomly from legal kindergarten and preschool in which the research is conducted. It is suggested to norm this scale adapted as a teacher form through issuing a parent form and applying in different age, socio economic level and residential areas in terms of generalize regarding its validity and reliability, and to analyze it from the point of different variables and test it in longitudinal studies.

\section{Acknowledgements}

I am so grateful to the school administrators and teachers for the dedication and support they showed during the implementation of the scale.

\section{References}

Akfirat-Onalan, F. (2006). Social competence social skill and creative drama. Journal of Creative Drama, 1(1), 39-58.

Aral, N., Baran, G., Bulut, Ş., \& Cimen, S. (2000). Social Development. Child development-2 (pp. 59-81). Istanbul:Ya-Pa Publishing.

Avcioglu, H. (2005). Teaching social skills with activities. Ankara: KOK Publishing.

Aydin, A. (1997). Child and adolescent psychology. Istanbul: Marmara University Foundation Publishing.

Bacanli, H. (2008). Social skill training (3rd ed.). Ankara: Prime Publishing.

Baron-Cohen, S., Leslie, A. M., \& Frith, U. (1985). Does the autistic child have a 'theory of mind'? Cognition, 21, 37-46. https://doi.org/10.1016/0010-0277(85)90022-8

Bartsch, K., \& Wellman, H. M. (1994). Children talk about the mind. Cambridge, UK: Cambridge University

Basaran, I. E. (1996). Educational psychology. Ankara: Rose Publishing. 
Berk, L. E. (2003). Child development. USA: Pearson.

Bridgett, D. J., Gartstein, M. A., Putnam, S. P., McKay, T., Iddins, E., Robertson, C., \& others. (2009). Maternal and contextual influences and the effect of temperament development during infancy on parenting in toddlerhood. Infant Behavior and Development, 32,103-116. https://doi.org/10.1016/j.infbeh.2008.10.007

Brislin, R. W., Lonner, W. J., \& Thorndike, R. M. (1973) Cross-Cultural Research Methods (3rd ed.). Canada, John Wiley \& Sons Pub.

Cagdas, A. (1997). The effects of communication language on the social development of 4-5 year old children.(Unpublished doctoral dissertation). Selçuk University Institute of Social Sciences, Konya, Turkey.

Cartledge, G., \& Milburn, J. F. (1983). Social skills assessment and teaching in the schools. Advances in School Psychology, 3, 175-235.

Cassidy, K. W., Werner, R. S., Rourke, M., \& Zubernish, S. B. (2003). The relationship between psychological understanding and positive social behaviors. Social Development, 12(2), 198-221. https://doi.org/10.1111/1467-9507.00229

Cohen, J. (2001). Social and emotional education: Core concepts and practices. In J. Cohen (Ed.), Caring classrooms intelligent schools the social emotional education of young children (pp. 3-29). New York: Teacher College Press.

Cole, D. A. (1987). Utility of confirmatory factor analysis in test validation research. Journal of Consulting and Clinical Psychology, 55, 584-594. https://doi.org/10.1037/0022-006X.55.4.584

Costin, S. E., \& Jones, D. C. (1992). Friendship as a facilitator of emotional responsiveness and prosocial interventions among young children. Developmental Psychology, 28(5), 941-947. https://doi.org/10.1037/0012-1649.28.5.941

DeVellis, R. F. (2003). Scale development theory and application (2nd ed.). USA: Sage.

Elias, M. J. (2001). Prepare children for the tests of life, not a life of tests. Education Week, 21(4), 40.

Elias, M. J. (2006). The connection between academic and social-emotional learning. In M. J. Elias \& H. Arnold (Eds.), The educator's guide to emotional intelligence and academic achievement (pp. 4-13). Thousand Oaks: Corwin Press.

Elias, M. J., \& Tobias, S. E. (1996). Social Problem Solving Interventions in the Schools. New York: The Guilford Press.

Elibol, G. S. (2008). Evaluation in terms of some variables of social skills of 5-year-old children. (Unpublished master's thesis). Ankara University Institute of Education Sciences, Ankara, Turkey.

Elksnin, L. K., \& Elksnin, N. (2006). Teaching Social-Emotional Skills at School and Home. Denver: Love Publishing Company.

Eminoglu, B. (2007). Investigation of the relationship between social behaviors of four-five-year-olds and parental behaviors. (Unpublished master's thesis). Gazi University Institute of Education Sciences, Ankara, Turkey.

Ergene, T. (2011). Psychosocial development. In Y. Ozbay\& S. Erkan (Eds.), Educational Psychology (pp.101-130). Ankara: Pegem Publishing.

Fawcett, L. M., \& Garton, A. F. (2005). The effect of peer collaboration on children's problem-solving ability. British Journal of Educational Psychology, 75(2), 157-169. https://doi.org/10.1348/000709904X23411

Figueras-Costa, D., \& Harris, P. L. (2001). Theory of mind development in deaf children: A nonverbal test of false belief understanding. Journal of Deaf Studies and Deaf Education, (6), 92-102. https://doi.org/10.1093/deafed/6.2.92

Fivush, R., Haden, C. A., \& Reese, E. (2006). Elaborating on elaborations: Role of maternal reminiscing style in cognitive and socioemotional development. Child Development, 77(6), 1568-1588.

https://doi.org/10.1111/j.1467-8624.2006.00960.x

Flavell, J. H. (2000). Development of children's knowledge about the mental world. International Journal of Behavioral Development, 24(1), 15-23. https://doi.org/10.1080/016502500383421

Frey, K. S., Nolen, S. B., Van Schoiack, E. L., \& Hirschstein, M. K., (2005). Effects of a school-based social-emotional competence program: Linking children's goals, attributions, and behavior. Applied Developmental Psychology, 26, 171-200. https://doi.org/10.1016/j.appdev.2004.12.002

Frith, U., \& Frith, C. D. (2003). Development and neurophysiology of mentalizing. https://doi.org/10.1098/rstb.2002.1218

Gander, M. J., \& Gardiner, H. W. (1998). Child and adolescent development. Ankara: İmge Publishing.

Gizir, Z. (2002). Investigation of the relationship between the development of social behaviors and self-esteem in four to 
five-year old children attending kindergarten (Unpublished master's thesis). Ankara University Institute of Science, Ankara, Turkey.

Goleman, D. (2000). Why Emotional Intelligence is more important than IQ. Istanbul: Varlik [Asset] Publication.

Gresham, F. M., \& Elliott, S. N. (1990). Social Skills Rating System-Secondary. Circle Pines, MN: American Guidance Service.

Gresham, F. M., Cook, C. R., Collins, T., Dart, E., Rasetshwane, K., Truelson, E., \& Grant, S. (2010). Developing a change-sensitive brief behavior rating scale as a progress monitoring tool for social behavior: An example using the social skills rating system-teacher form. School Psychology Review, 39(3), 364-379.

Grusec, J. E., \& Davidov M. (2010). Integrating different perspectives on socialization theory and research: A domain-specific approach. Child Development, 81(3), 687-709. https://doi.org/10.1111/j.1467-8624.2010.01426.x

Gulay, H. (2009). Variables affecting the social status of 5-6 year old children. Journal of Yuzuncu Yll University Faculty of Education. 6(1), 104-121.

Gulay, H., \& Akman, B. (2009). Social skills at the preschool stage. Ankara: Pegem Publishing.

Hambleton, R. K. (2005). Issues, designs, and technical guidelines for adapting tests into multiple languages and cultures. In R.K. Hambleton, P. F. Merenda, \& C. D. Spielberger (Eds.), Adapting Educational and Psychological Tests for Cross-Cultural Assessment (pp.3-38). Mahwah, N.J.: Lawrence Erlbaum Associates, Publishers.

Herold, R., Tényi, T., Lénárd, K., \& Trixler, M. (2002). Theory of mind deficit in people with schizophrenia during remission. Psychol. Med., 32, 1125-1129. https://doi.org/10.1017/S0033291702005433

Howes, C. (2009). Friendship in early childhood. In K.H.Rubin, W.M., Bukowski \& B. Laursen (Eds.), Handbook of peer interactions, relationships, and groups (pp.180-194). New York: Guilford.

Ironsmith, M., \& Poteat, G. M. (1990). Behavioral correlations of preschool sociometric status and the prediction of teacher ratings of behavior in kindergarten. Journal of Clinical Child Psychology, 19(1), 17-25. https://doi.org/10.1207/s15374424jccp1901_3

Joseph, G. E., \& Strain, P. S. (2003). Comprehensive evidende-based social-emotional curricula for young children: an analysis of efficacious adoption potential. Topics In Early Childhood Special Education, 23(2), 65-76. https://doi.org/10.1177/02711214030230020201

Kandir, A., \& Alpan, Y. (2008). Application at different socio-economic levels of social emotional evaluation tool (ITSEA). Journal of Turkish Educational Sciences, 6(1), 41-61. Retrieved from http://www.tebd.gazi.edu.tr/index.php/tebd/article/viewFile/146/133

Kara, Y., \& Cam, F. (2007). Effect of creative drama method on the reception of some social skills. Hacettepe University Journal of Education Faculty, 32, 145-155.

Kline, R. B. (2005), Principles and practice of structural equation modeling (2nd ed.). New York: The Guilford Press.

Kusché, C. A., \& Greenberg, M. T. (2001). PATHS in your classroom: Promoting emotional literacy and alleviating emotional distress. In J. Cohen (Ed.), Caring classrooms intelligent schools the social emotional education of young children (pp.140-161). New York: Teacher College Press.

Lindsey, E. V., \& Colwell, M. J. (2003). Preschooler's emotional competence: Links to pretend and physical play. Child Study Journal, 33(1), 39-52. Retrieved from http://eds.b.ebscohost.com/eds/pdfviewer/pdfviewer? vid=1\&sid=f06c4eb8-861a-4c03-b190-353cb9 bfcbb1\%40sessionmgr198\&hid=121

Marlow, L., Bloss K., \& Bloss, D. (2000). Promoting social and emotional competency through teacher/counselor collaboration. Education, 120, 668-674.

Marschark, M., Green, V., Hinmarsch, G., \& Walker, S. (2000). Understanding theory of mind in children who are deaf. Journal of Child Psychology and Psychiatry, 41, 1067-1073. https://doi.org/10.1111/1469-7610.00694

McKenzie, M. (2004). Seeing the spectrum: North american approaches to emotional, social and moral education. The Educational Forum, 69(1), 79-90. https://doi.org/10.1080/00131720408984667

Merrell, K. W., \& Caldarella, P. (2002). Home and community social behavior scales. Jowa City, IA: Assessment-Intervention Resources. Retrieved from http://www.assessment-intervention.com

Merrell, K. W., Felver-Gant, J. C., \& Karalyn, M. T. (2011). Development and validation of a parent report measure for assessing social-emotional competencies of children and adolescents. J Child Fam Stud, 20, 529-540. https://doi.org/10.1007/s10826-010-9425-0

Miller, P. H. (2008). Theories of developmental psychology. Ankara: Imge Publishing.

Oktay, A. (2004). The magic years of life: Preschool stage. Istanbul: Epsilon Publishing. 
Omeroglu, E., Buyukozturk, S., Aydoğan, Y., Cakan, M., Cakmak, E. K., Ozyurek, A.... Karayol, S. (2014). Preschool Teacher Form Development of Social Skills Rating Scale: Reliability and Validity Analysis. Education and Society in the 21st Century, 3(8), 37-46.

http://dergipark.ulakbim.gov.tr/egitimvetoplum/article/viewFile/5000112832/5000105076

Ozden, Y. (1999). Learning and teaching. Ankara Pegem A Publishing.

Pasi, R. J. (2001). Higher expectations promoting social emotional learning and academic achievement in your school. New York: Teacher College Press.

Patti, J., \& Lantieri, L. (1999). Waging peace in our schools social and emotional learning through conflict resolution. In J. Cohen (Ed.), Educating minds and hearts social emotional learning and the passage into adolescence (pp.126-136). New York: Teachers College Press.

Payton, W. J., Wardlaw, D. M., Graczyk, P. A., Bloodworth, M. R., Tompsett, C. J., \& Weissberg, R. P. (2000). Social and emotional learning: a framework for promoting mental health and reducing risk behaviors in children and youth. Journal Of School Health, 70(5), 179-185. https://doi.org/10.1111/j.1746-1561.2000.tb06468.x

Poole, C., Miller, S., \& Church, E. (2003). How children build friendships. Early Childhood Today, 18(2). Accession Order No. 11100926

Ramani, G. B., Brownell, C. A., \& Campbell, S. B. (2010). Positive and negative peer interaction in 3-and 4-Year-Olds in relation to regulation and dysregulation. The Journal of Genetic Psychology, 171(3), 218-250. https://doi.org/10.1080/00221320903300353

Salkind, N. J. (2004). An introduction to theories of human development. USA: Sage Publications. https://doi.org/10.4135/9781483328676

Santrock, J. W. (2015). Cognitive development in infancy. In G. Yuksel (Ed.), Lifelong development: Developmental psychology (pp. 145-176). Ankara: Nobel Publishing.

Sari, E. (2007). An investigation of the effects of mothers child rearing attitudes on child's social cohesion and skills for 5-6 years old child's who attend kindergarten. (Unpublished master's thesis). Gazi University Institute of Education Sciences, Ankara, Turkey.

Senemoglu, N. (2011). Developmental learning and teaching: From theory to practice. Ankara:Pegem Publishing.

Sorias, O. (1986). Social skills and assessment methods. Journal of Psychology, 5(20), 24-29. Retrieved from www.behavioradvisor. com/socialskills.htm

Sumer, N. (2000). Structural equation models: Basic concepts and sample applications. Turkish Psychology Articles, $3(6), 49-74$.

Tezbasaran, A. (1997). Likert type scale development guide (2nd ed.). Ankara: Turkish Psychological Association Publication.

Trentacosta, C. J., \& Fine, S. E. (2009). Emotion knowledge, social competence, and behavior problems in childhood and adolescence: A meta-analytic review. Social Development, 19(1), 1-29. https://doi.org/10.1111/j.1467-9507.2009.00543.x

Westwood, P. (1993). Commonsense methods for children with special needs strategies for the regular classrom. London. https://doi.org/10.4324/9780203426692

Yavuzer, H. (2000). The first six years of your child with physical mental and social development. Istanbul: Remzi Bookstore.

Zins, J. E., \& Wagner, D. I. (1997). Educating children and youth for psychological competence. In R.J. Illback, \& C.T. Cobb (Eds.), Integrated services for children and families: Opportunities for psychological practice (pp. 137-156). Washington, DC: American Psychological Association. https://doi.org/10.1037/10236-007

\section{Copyrights}

Copyright for this article is retained by the author(s), with first publication rights granted to the journal.

This is an open-access article distributed under the terms and conditions of the Creative Commons Attribution license which permits unrestricted use, distribution, and reproduction in any medium, provided the original work is properly cited. 